\title{
Modifikasi Pengering Tipe Tray Dryer Dengan Penambahan Insulator
} (Modification Of Tray Dryer With Insulator)

\author{
Iqbal Fahri Tobing ${ }^{1}$, Mustaqimah ${ }^{1}$, Raida Agustina ${ }^{\text {* }}$ \\ ${ }^{1}$ Program Studi Teknik Pertanian Fakultas Pertanian Universitas Syiah Kuala \\ *Corresponding author : raidaagustina@unsyiah.ac.id
}

\begin{abstract}
Abstrak. Pengering tipe Tray Dryer merupakan salah satu alat pengering rak atau pengering kabinet yang dapat digunakan untuk mengeringkan berbagai jenis bahan baku makanan. Alat pengering ini dirancang dengan tipe paralel flow tray dimana udara panas yang dihasilkan akan disirkulasikan sejajar dengan permukaan rak pengering dan bekerja menggunakan sumber energi listrik. Penelitian ini bertujuan untuk memodifikasi pengering tray dryer dengan penambahan insulator dan mengetahui konsumsi energi alat pengering tray dryer pada pengeringan kunyit. Parameter pengujian uji kinerja alat tanpa bahan meliputi distribusi suhu, kelembaban relatif dan kecepatan aliran udara dan untuk perhitungan konsumsi energi meliputi penggunaan energi listrik, perhitungan energi thermal, energi mengeringkan bahan, energi untuk menguapkan air bahan, efisiensi pengeringan, energi kipas dan kehilangan energi melalui cerobong. Pada pengujian pengering tray dryer suhu yang digunakan adalah $55^{\circ} \mathrm{C}$. Hasil penelitian menunjukkan bahwa secara fungsional dan struktural alat pengering tray dryer setelah dimodifikasi dengan melapisi dinding luar ruang pengering dapat beroperasi dengan baik, proses pengeringan lebih cepat dan energi yang digunakan juga sedikit dibandingkan dengan sebelum dimodifikasi. Konsumsi energi listrik pada alat pengering tray dryer setelah dimodifikasi pada saat proses pengeringan dengan suhu $35^{\circ} \mathrm{C}$ selama 6,5 jam sebesar $35,33 \mathrm{kWh}(127,2$ MJ), pada suhu $45^{\circ} \mathrm{C}$ sebesar $24,26 \mathrm{kWh}(88,06 \mathrm{MJ})$ dengan lamanya pengeringan selama 4,5 jam dan suhu $55^{\circ} \mathrm{C}$ sebesar 18,89 $\mathrm{kWh}(68,01 \mathrm{MJ})$ dengan lama pengeringan selama 3,5 jam, hal ii disebabkan lama pengeringan merupakan salah satu faktor yang menyebabkan besar kecilnya konsumsi energi listrik. Konsumsi energi thermal selama proses pengeringan dengan suhu $35^{\circ} \mathrm{C}$ adalah sebesar $17,53 \mathrm{MJ}$, suhu $45^{\circ} \mathrm{C}$ sebesar $19,54 \mathrm{MJ}$ dan suhu $55^{\circ} \mathrm{C}$ sebesar 21,34 MJ. Berdasarkan hasil kalkulasi antara energi listrik dan energi thermal didapatkan efisiensi pengeringan pada suhu $35^{\circ} \mathrm{C}$ sebesar $27,80 \%$, suhu $45^{\circ} \mathrm{C}$ sebesar $22,2 \%$ dan suhu $55^{\circ} \mathrm{C}$ sebesar 31,4\%.
\end{abstract}

Kata Kunci : Tray Dryer, Insulator, Kunyit, Konsumsi Energi

Abstract. Tray Dryer is a type of dryer or cabinet dryer that can be used to dry various types of food raw materials. This dryer is designed with a parallel flow tray type where the hot air generated will be circulated parallel to the surface of the drying rack and work using an electric energy source. This study aims to modify the tray dryer with the addition of an insulator and determine the energy consumption of dryer in turmeric drying. The test parameters of the performance test of equipment without material include temperature distribution, relative humidity and air flow velocity and for the calculation of energy consumption including the use of electrical energy, thermal energy calculation, energy drying material, energy to evaporate material water, drying efficiency, fan energy and energy loss through chimney. In testing the tray dryer the temperature used is $55^{\circ} \mathrm{C}$. The results showed that functionally and structurally the tray dryer after being modified by covering the outer walls of the drying chamber could operate well, the drying process was faster and the energy used was also less compared to before it was modified. Electric energy consumption in the tray dryer after being modified during the drying process with a temperature of $35^{\circ} \mathrm{C}$ for 6.5 hours amount to $35.33 \mathrm{kWh}(127.2$ $\mathrm{MJ})$, at a temperature of $45^{\circ} \mathrm{C}$ of $24.26 \mathrm{kWh}(88.06 \mathrm{MJ})$ with a duration drying for 4.5 hours and a temperature of $55^{\circ} \mathrm{C}$ of $18.89 \mathrm{kWh}(68.01 \mathrm{MJ})$ with a drying time of 3.5 hours, this is due to the length of drying is one of the factors causing the size of the electrical energy consumption. The consumption of thermal energy during the drying process with a temperature of $35^{\circ} \mathrm{C}$ is $17.53 \mathrm{MJ}$, a temperature of $45^{\circ} \mathrm{C}$ is $19.54 \mathrm{MJ}$ and a temperature of $55^{\circ} \mathrm{C}$ is $21.34 \mathrm{MJ}$. Based on the results of calculations between electrical energy and thermal energy obtained drying efficiency at a temperature of $35^{\circ} \mathrm{C}$ at $27.80 \%$, a temperature of $45^{\circ} \mathrm{C}$ at $22.2 \%$ and a temperature of $55^{\circ} \mathrm{C}$ at $31.4 \%$

Keywords: Tray Dryer, Insulator, Turmeric, Energy Consumption 


\section{PENDAHULUAN}

Insulator yaitu bahan yang sukar atau tidak dapat sama sekali menghantarkan aliran listrik. Sangat baik bila dipakai untuk menyekat atau mengisolasi bahan penghantar atau memisahan bagian-bagian yang bertegangan atau bagian-bagian yang aktif. Oleh karena itu bahan insulator berkaitan dengan pemisahan bagian-bagian yang bertegangan maka sifat kelistrikan menjadi bagian yang sangat penting untuk dipelajari, selain itu sifat mekanis, sifat thermal juga sifat kimiawi perlu juga diperhatikan.

Tray dryer ini menggunakan alat-alat elektronik sehingga di butuhkan energi untuk menggerakkan alat-alat tersebut, salah satu bahan bakar yang digunakan yaitu energi listrik. tray dryer ini menggunakan energi listrik perlu di konsumsi energi agar dapat kita ketahui bahwa alat ini ukuran tingkat penggunaan sumber daya dalam suatu proses. Semakin hemat atau sedikit penggunaan sumber daya, maka prosesnya dikatakan semakin efisien.

Penelitian ini bertujuan untuk memodifikasi pengering Tray dryer dengan penambahan insulator dan mengetahui konsumsi energi alat pengering Tray dryer pada pengeringan kunyit.

\section{METODE PENELITIAN}

\section{Tempat dan Waktu}

Penelitian ini dilaksanakan pada Bulan Desember 2018. Penelitian ini dilakukan di Laboratorium Teknik Pasca Panen Program Studi Teknik Pertanian, Universitas Syiah Kuala, Darussalam Banda Aceh. .

\section{Alat dan Bahan}

Peralatan yang digunakan dalam penelitian ini adalah alat pengering tray dryer, stopwatch, termometer, timbangan digital, Kalkulator, Anemometer. Bahan yang digunakan dalam penelitian ini adalah busa alumunium foil dan kunyit.

\section{Prosedur Penelitian}

Pertama menyiapkan bahan insulator yang baik untuk digunakan dalam proses modifikasi tray dryer selanjutnya dipasang pada dinding luar tray dryer, kedua uji alat tanpa bahan dilakukan dengan parameter seperti distribusi suhu menggunakan termometer, kelembaban relatif menggunakan tbk dan tbb dan kecepatan aliran udara menggunakan anemometer pengukuran setiap 10 menit sekali. Ketiga konsumsi energi pada proses pengeringan kunyit yang akan dianalisis antara lain konsumsi energi listrik, konsumsi energi thermal, konsumsi energi mengeringkan bahan, konsumsi energi menguapkan air bahan, konsumsi energi kipas, efisiensi pengeringan, energi biologis manusia dan kehilangan energi melalui cerobong. 


\section{Analisa Data}

1. Analisis Perhitungan Penggunaan Energi Listrik

Menurut Eugene C (1993) Energi yang digunakan alat listrik merupakan laju penggunaan energi (daya) dikalikan dengan waktu selama alat itu digunakan. Bila daya diukur dalam watt jam, dengan persamaan:

$\mathrm{W}=\mathrm{PXt}$

Dimana :

$\mathrm{W}=$ Energi listrik yang digunakan pada pengeringan Kunyit (MJ)

$\mathrm{t} \quad=$ Waktu pemakaian alat (detik)

$\mathrm{P} \quad=$ Daya alat $/$ mesin terukur (Watt)

2. Energi yang digunakan untuk mengeringkan bahan.

Menurut Swara (2007) Kalor dapat mengubah suhu suatu benda dan akhirnya dapat mempengaruhi bentuk atau wujudnya. Banyaknya kalor yang diperlukan untuk menaikkan suhu suatu benda sebanding dengan massa benda dan kenaikan suhunya dapat dihitung dengan persamaan:

$\mathrm{Q}_{1}=\mathrm{m} \times \mathrm{c} \times\left(\mathrm{t}_{1}-\mathrm{t}_{0}\right)$

Dimana :

$\mathrm{Q}_{1} \quad=$ Energi untuk mengeringkan bahan $(\mathrm{J})$

$\mathrm{m} \quad=$ massa bahan $(\mathrm{kg})$

$\mathrm{c} \quad=$ kalor jenis $(\mathrm{j} / \mathrm{kg})$, kalor spesifik kunyit menggunakan persamaan (Siebel, 1892)

$=0,837+0,034\left(\mathrm{KA}_{0}\right)$

$\mathrm{T}_{0} \quad=$ Suhu awal $\left({ }^{\circ} \mathrm{C}\right)$

$\mathrm{T}_{1} \quad=$ Suhu akhir $\left({ }^{\circ} \mathrm{C}\right)$

4. Energi untuk menguapkan air bahan.

Menurut Swara (2007), Pada waktu melebur atau mencair, suhu zat tetap. Semua kalor yang diberikan kepada zat digunakan untuk mengubah wujud dari padat ke cair. Suhu tetap itu disebut titik lebur, yang besarnya sangat tergantung pada tekanan di permukaan zat itu dapat dihitung dengan persamaan :

$\mathrm{Q}_{2}=\mathrm{m}$. L

Dimana :

$\mathrm{Q}_{2} \quad=$ Energi yang digunakan untuk menguapkan air bahan $(\mathrm{J})$

$\mathrm{m} \quad=$ massa bahan $(\mathrm{kg})$

$\mathrm{L} \quad=$ Kalor laten $(\mathrm{j} / \mathrm{kg})=22,6 \times 10^{5} \mathrm{j} / \mathrm{kg}$

5. Analisis Perhitungan Penggunaan Energi Thermal.

Menurut Kamaruddin (1994) Energi Thermal untuk proses pengeringan (QT) ditentukan dengan persamaan 2:

$\mathrm{Q}_{\mathrm{T}}=\mathrm{Q}_{1}+\mathrm{Q}_{2}$

Dimana :

$\mathrm{Q}_{\mathrm{T}} \quad=$ Energi yang dibutuhkan dalam proses pengeringan $(\mathrm{MJ})$

$\mathrm{Q}_{1} \quad=$ Energi yang digunakan untuk mengeringkan bahan (MJ)

$\mathrm{Q}_{2} \quad=$ Energi yang digunakan untuk menguapkan air bahan (MJ)

6. Analisis Perhitungan Penggunaan Energi kipas.

Menurut kamarudin (1994) untuk menghitung energi kipas dapat dirumuskan sebgai berikut.

$\mathrm{Q} 3=\mathrm{P} \times \mathrm{t}$.

Dimana : 
$\begin{array}{ll}\mathrm{P} & \text { : Daya Kipas (Watt) } \\ \mathrm{t} & : \text { Waktu (s) }\end{array}$

7. Energi Hilang Melalui Cerobong.

Menurut Maulana (2014), energi hilang melalui cerobong dapat dihitung dengan persamaan sebagi berikut.

$\mathrm{Qlv}=\left(\mathrm{v} \times \mathrm{C}_{\mathrm{pw}} \times\left(\mathrm{t}_{1}-\mathrm{t}_{0}\right)\right) / \mathrm{N}$

Dimana :

Qlv : Energi hilang melalui cerobong $(\mathrm{j} / \mathrm{kg})$

$\mathrm{V} \quad$ : Kecepatan udara $(\mathrm{m} / \mathrm{det})$

$\mathrm{C}_{\mathrm{pw}} \quad$ : Panas jenis udara $\left(1000 \mathrm{j} / \mathrm{kg}^{\circ} \mathrm{C}\right)$

$\mathrm{t}_{0} \quad$ : suhu awal $\left({ }^{\circ} \mathrm{C}\right)$

$\mathrm{t}_{1} \quad$ : suhu akhir $\left({ }^{\circ} \mathrm{C}\right)$

$\mathrm{N} \quad$ : Lama pengeringan (det)

\section{HASIL DAN PEMBAHASAN}

\section{Uji Kinerja Alat Pengering Tray Dryer Tanpa Beban}

Uji kinerja alat pengering tray dryer dilakukan dengan tanpa menggunakan beban. Pengujian yang dilakukan yaitu pengukuran data yang meliputi pengukuran distribusi suhu menggunakan termometer yang diletakkan pada ruang pemanas, ruang pengering dan cerobong. Pengukuran kelembaban relatif $(\mathrm{RH})$ menggunakan TBK dan TBB dan pengukuran kecepatan aliran udara menggunakan anemometer.

\section{Distribusi Suhu}

Suhu merupakan hal yang penting dalam suatu proses pengeringan, dimana semakin tinggi suhu, semakin cepat terjadinya laju pengeringan.

\section{Distribusi Suhu $55^{\circ} \mathrm{C}$}

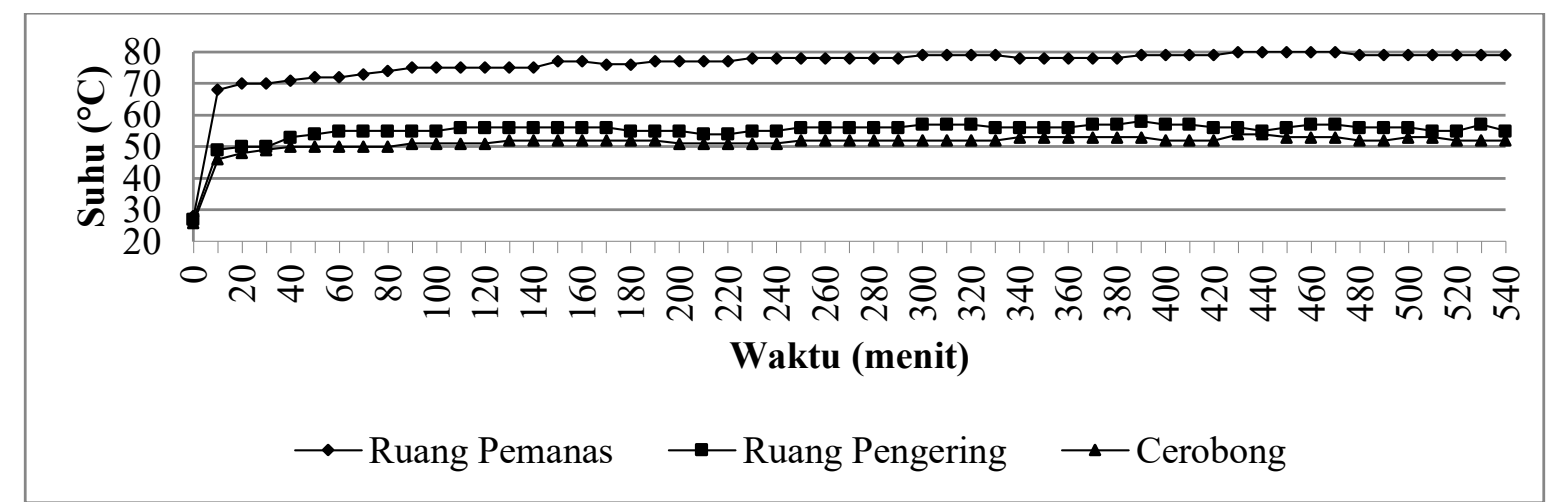

Gambar 1. Suhu $55^{\circ} \mathrm{C}$ Pada Alat Pengering Tray Dryer

Berdasarkan pada Gambar 1 Pada ruang pemanas didapatkan nilai rata-rata distribusi suhu didapatkan sebesar $78,7{ }^{\circ} \mathrm{C}$ hal ini disebabkan letak termometer dekat dengan heater Pada ruang pengering nilai rata-rata distribusi suhu didapatkan sebesar $56,0{ }^{\circ} \mathrm{C}$. Pada 
cerobong untuk nilai rata-rata distribusi suhu didapatkan sebesar $52,0^{\circ} \mathrm{C}$ hal ini disebabkan letak termometer jauh dengan heater sehingga suhu di cerobong lebih rendah dari ruangan lainnya.

\section{Kelembaban Relatif (RH)}

Pada penelitian ini pengukuran kelembaban relatif $(\mathrm{RH})$ dilakukan dengan meletakan termometer bola basah (tbb) dan termometer bola kering (tbk) di ruang pengering, kemudian hasil pengukuran yang tercatat akan diakumulasikan dengan menggunakan kalkulator RH untuk mendapatkan nilai kelembaban relatif (RH).

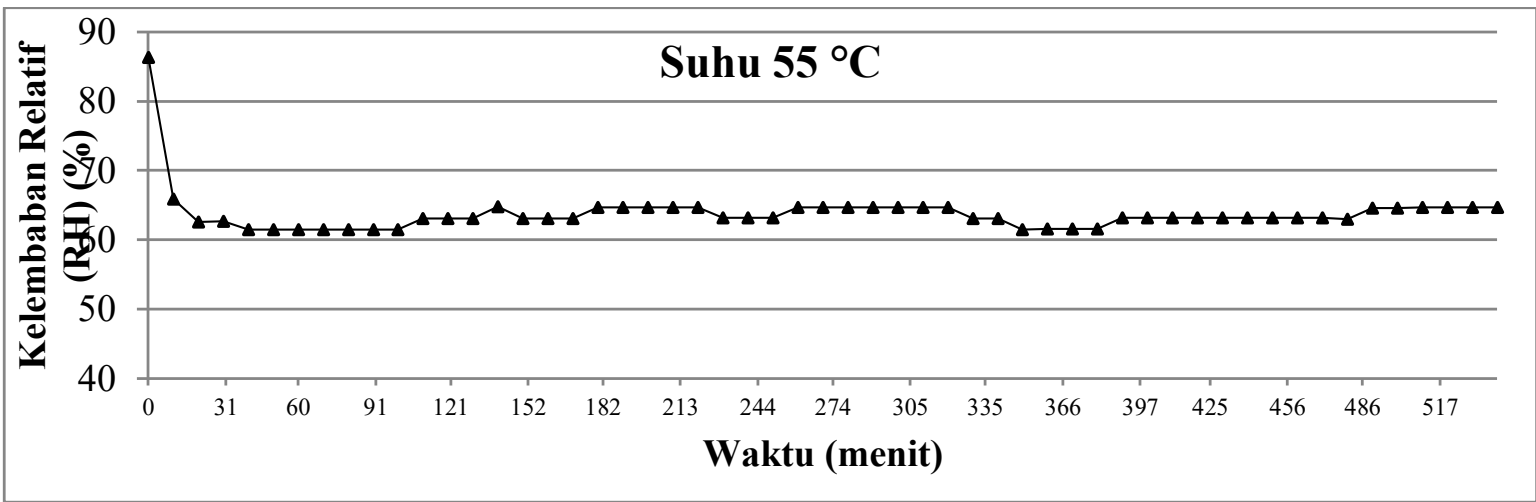

Gambar 2. Hubungan Kelembaban Relatif Pada Alat Pengering Tray Dryer

Berdasarkan Gambar 2 dapat dilihat bahwa untuk pengukuran nilai kelembaban relatif $(\mathrm{RH})$ yang didapatkan pada suhu $55^{\circ} \mathrm{C}$ didapatkan yang tertinggi sebesar $66,7 \%$ dan nilai kelembaban relatif $(\mathrm{RH})$ terendah yaitu sebesar $61,5 \%$ dan untuk nilai rata-rata kelembaban relatif (RH) didapatkan sebesar 63,9\%. Kelembaban relatif $(\mathrm{RH})$ yang ideal untuk proses pengeringan adalah $60-70 \%$.

\section{Kecepatan Aliran Udara}

\section{Kecepatan Aliran udara Inlet dan Outlet}

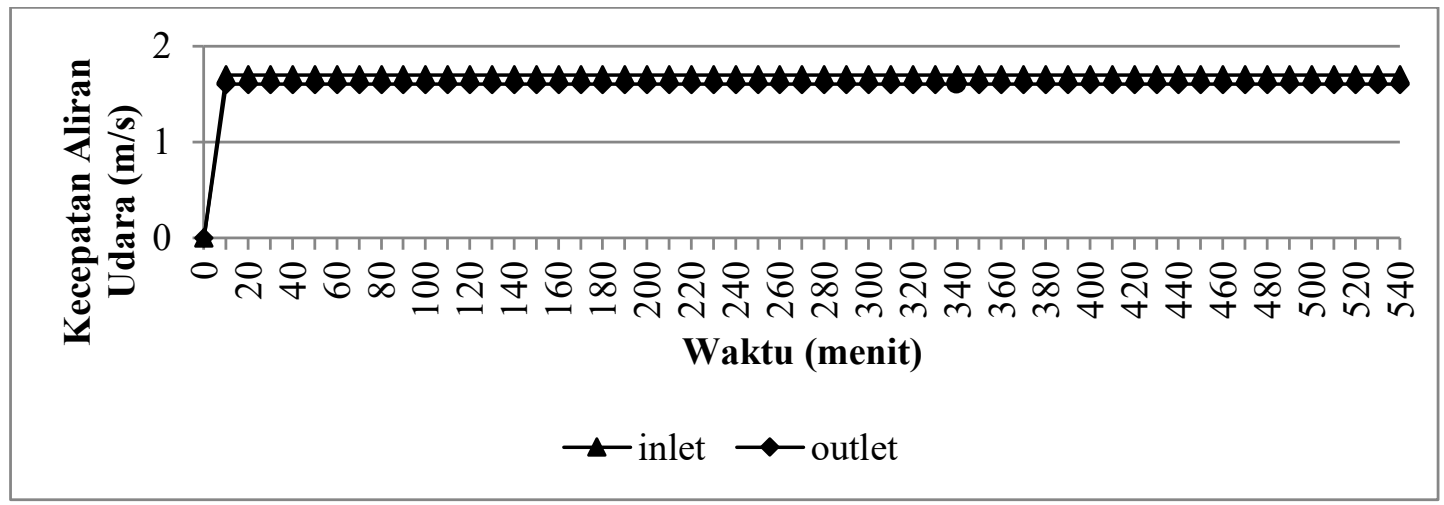

Gambar 3. Rata - Rata Kecepatan Aliran Udara Inlet dan Outlet

Berdasarkan pada Gambar 3 dapat dilihat bahwa pengukuran kecepatan aliran udara inlet pada Pada suhu $55{ }^{\circ} \mathrm{C}$ didapatkan nilai rata-rata kecepatan aliran udara pada inlet 
didapatkan sebesar $1,6 \mathrm{~m} / \mathrm{s}$. Pada suhu $55^{\circ} \mathrm{C}$ didapatkan nilai rata-rata kecepatan aliran udara pada outlet didapatkan sebesar 1,43 m/s. Jika kecepatan aliran udara pengering semakin tinggi maka semakin cepat pula masa uap air yang dipindahkan dari bahan ke atmosfer.Akan tetapi jika kecepatan aliran udara terlalu tinggi menyebabkan udara panas yang seharusnya berada dalam ruang pengering untuk mengeringkan bahan menjadi terbawa keluar ruang pengering sebelum digunakan untuk mengeringkan bahan

\section{Konsumsi Energi Listrik Menggunakan Bahan}

\begin{tabular}{lcccccc}
\multicolumn{2}{c}{ Tabel 1. Komponen dan energi listrik suhu $35^{\circ} \mathrm{C}, 45^{\circ} \mathrm{C}$ dan $55^{\circ} \mathrm{C}$} \\
\cline { 2 - 8 } Komponen & \multicolumn{3}{c}{$35^{\circ} \mathrm{C}$} & \multicolumn{2}{c}{$45^{\circ} \mathrm{C}$} & \multicolumn{2}{c}{$55^{\circ} \mathrm{C}$} \\
\cline { 2 - 8 } & Jumlah & $\begin{array}{c}\text { Energi } \\
\text { listrik } \\
(\mathrm{kWh})\end{array}$ & Jumlah & $\begin{array}{c}\text { Energi listrik } \\
(\mathrm{kWh})\end{array}$ & Jumlah & $\begin{array}{c}\text { Energi } \\
\text { listrik } \\
(\mathrm{kWh})\end{array}$ \\
\hline Heater & 1 & 12,6 & 1 & 8,8 & 1 & 6,8 \\
Timbangan & 1 & 14,3 & 1 & 9,9 & 1 & 7,7 \\
Kipas & 2 & 0,49 & 2 & 0,34 & 1 & 0,13 \\
Termostart & 1 & 7,87 & 1 & 5,45 & 1 & 4,24 \\
\hline Total energi listrik & & 35,33 & & 24,26 & & 18,89
\end{tabular}

Tabel 1 menunjukkan pengeringan irisan kunyit pada suhu $35^{\circ} \mathrm{C}$ menggunakan energi listrik yang lebih besar $35,33 \mathrm{kWh}(127,2 \mathrm{MJ})$ dari pada pengeringan di suhu $45^{\circ} \mathrm{C}$ sebesar $24,26 \mathrm{kWh}(88,06 \mathrm{MJ})$ dan suhu $55^{\circ} \mathrm{C}$ sebesar $18,89 \mathrm{kWh}(68,01 \mathrm{MJ})$. Hal ini disebabkan karena lama proses pengeringan kunyit pada suhu $35^{\circ} \mathrm{C}$ mencapai 6,5 jam sedangkan suhu $45^{\circ} \mathrm{C}$ dan suhu $55^{\circ} \mathrm{C}$ hanya mencapai 4,5 jam dan 3,5 jam. Hal ini dikarenakan lama pengeringan merupakan salah satu faktor yang menyebabkan besar kecilnya konsumsi energi listrik pada alat pengering tipe tray dryer, selain faktor daya dari tiap komponen dan jumlah komponen yang digunakan.

\section{Konsumsi Energi Mengeringkan Bahan}

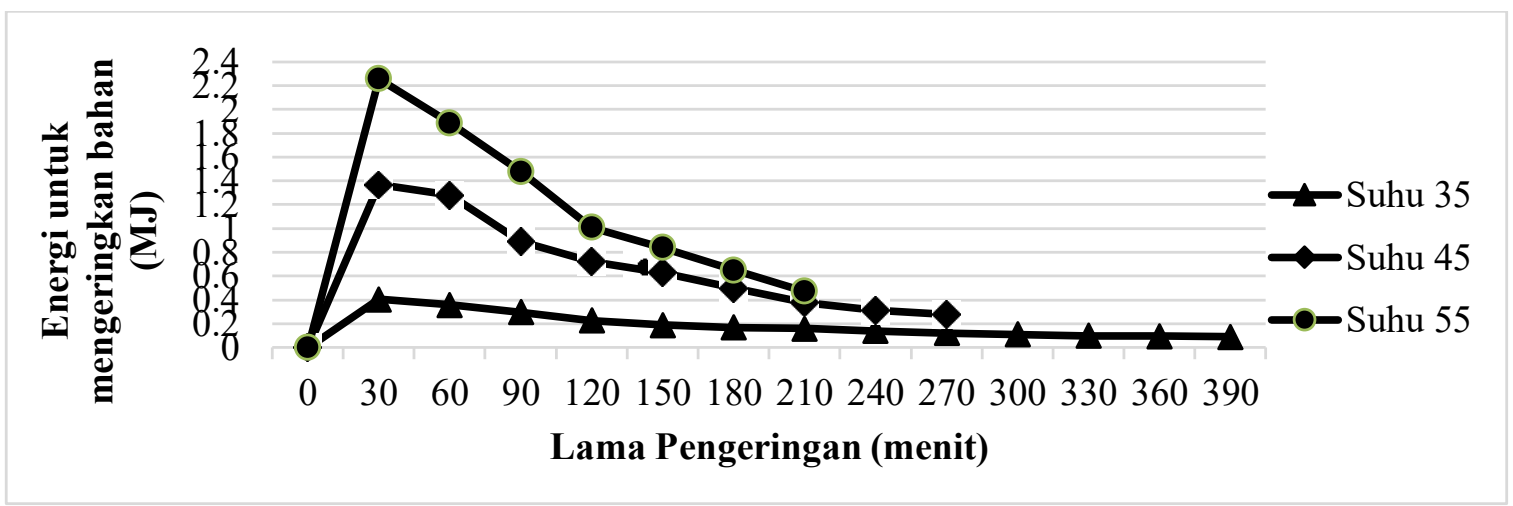

Gambar 4. Energi Untuk Mengeringkan Bahan 
Berdasarkan pada Gambar 4 pada suhu $35^{\circ} \mathrm{C}$ didapatkan total energi sebesar 2,47 $\mathrm{MJ}$, suhu $45^{\circ} \mathrm{C}$ sebesar $6,36 \mathrm{MJ}$ dan suhu $55^{\circ} \mathrm{C}$ didapatkan total energi sebesar 8,59 MJ. Perubahan massa bahan selama proses pengeringan berlangsung merupakan salah satu faktor yang mempengaruhi tingkat konsumsi energi untuk mengeringkan bahan selain faktor suhu pengeringan. Semakin besar suhu ruang pengering, maka semakin besar pula energi untuk mengeringkan bahan sedangkan semakin rendah suhu ruang pengering, maka semakin kecil pula energi yang dibutuhkan untuk mengeringkan bahan.

\section{Konsumsi Energi Menguapkan Air Bahan}

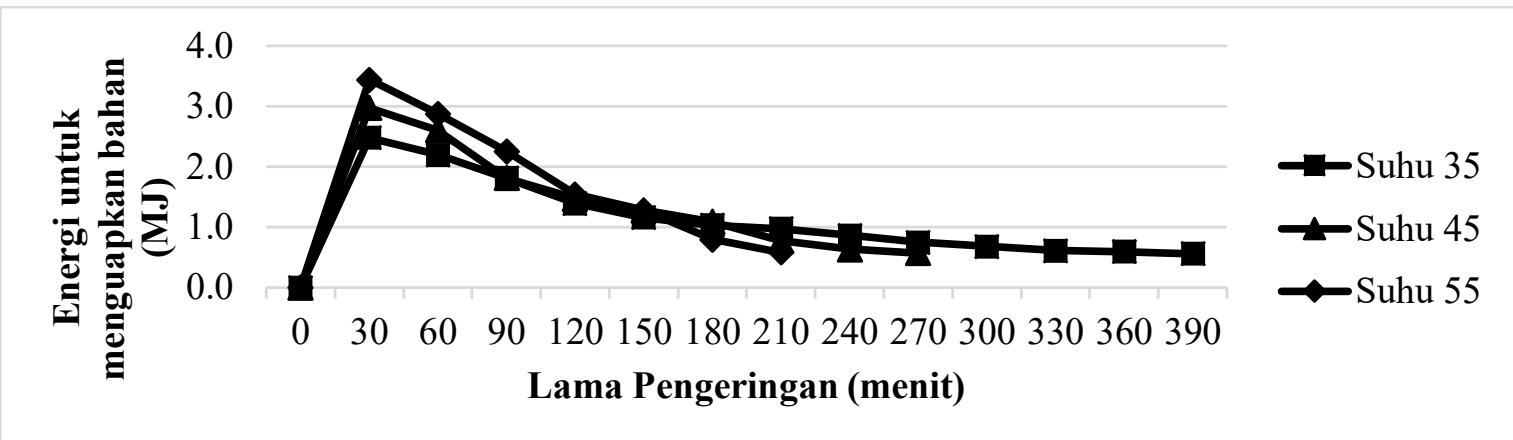

Gambar 5. Energi Untuk Menguapkan Air Bahan

Berdasarkan pada Gambar 5 pada suhu $35^{\circ} \mathrm{C}$ didapatkan total energi sebesar 15,1 $\mathrm{MJ}$, suhu $45^{\circ} \mathrm{C}$ total energi sebesar 13,2 MJ dan suhu $55^{\circ} \mathrm{C}$ sebesar 12,7 MJ. Penggunaan energi untuk menguapkan air bahan terjadi karena faktor perbedaan suhu pada ruang pengering dengan bahan yang dikeringkan sehingga berpengaruh terhadap perubahan massa bahan yang diakibatkan oleh menguapnya air dari dalam bahan ke udara.

\section{Konsumsi Energi Thermal}

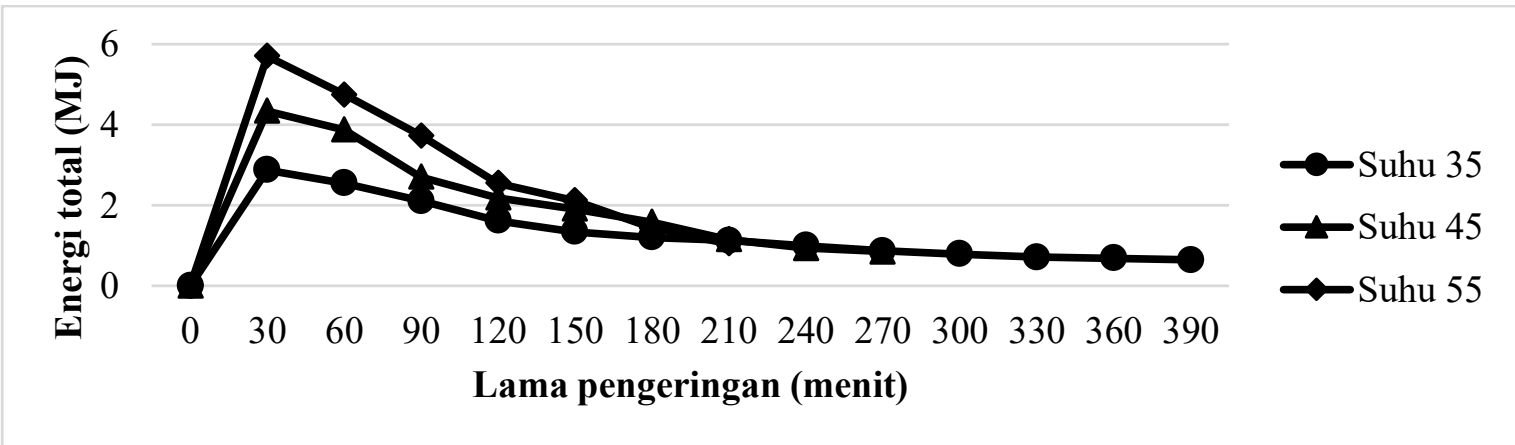

Gambar 6. Energi Thermal Pada Proses Pengeringan

Berdasarkan pada Gambar 6 Pada suhu $35^{\circ} \mathrm{C}$ didapatkan total energi thermal sebesar 17,53 MJ, pada suhu $45^{\circ} \mathrm{C}$ sebesar $19,54 \mathrm{MJ}$ dan suhu $55^{\circ} \mathrm{C}$ total energi thermal sebesar 21,34 MJ. Pada suhu $55^{\circ} \mathrm{C}$ didapatkan energi thermal lebih besar disebabkan oleh proses pengeringan lebih cepat. Hasil Penelitian menunjukkan semakin rendah suhu pengeringan maka semakin rendah nilai konsumsi energi thermalnya.

Modifikasi Pengering Tipe Tray Dryer Dengan Penambahan Insulator (Iqbal Fahri Tobing, Mustaqimah, Raida Agustina*)

Jurnal Ilmiah Mahasiswa Pertanian Unsyiah, Vol. 5, No. 4, November 2019: 1-10 


\section{Efisiensi Pengeringan}

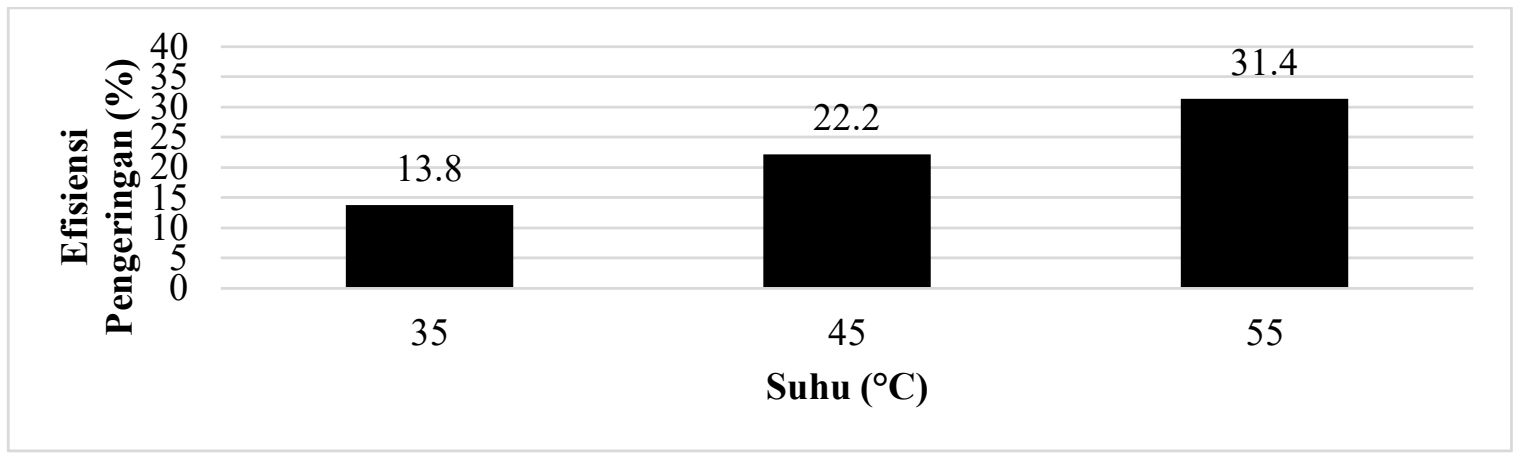

Gambar 7. Efisiensi Pengeringan pada suhu $35^{\circ} \mathrm{C}, 45^{\circ} \mathrm{C}$ dan $55^{\circ} \mathrm{C}$

Berdasarkan pada Gambar 7 pada suhu $35^{\circ} \mathrm{C}$ total efisiensi pengeringan didapatkan sebesar $13,8 \%$, pada suhu $45^{\circ} \mathrm{C}$ sebesar $22,2 \%$ dan suhu $55^{\circ} \mathrm{C}$ total efisiensi sebesar $31,4 \%$

\section{Konsumsi Energi Biologis Manusia}

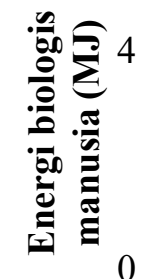

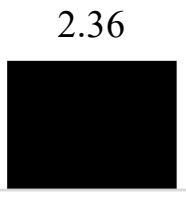

6.5
1.63

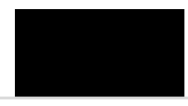

4.5
1.27

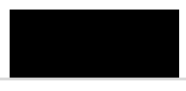

3.5

Jam

Gambar 8. Energi Biologis pada saat proses pengeringan

Berdasarkan pada Gambar 8 pada suhu $35^{\circ} \mathrm{C}$ total konsumsi energi biologis manusia didapatkan sebesar 2,36 MJ, pada suhu $45^{\circ} \mathrm{C} 1,63 \mathrm{MJ}$ dan suhu $55^{\circ} \mathrm{C} 1,27 \mathrm{MJ}$. Semakin tinggi suhu pengering kebutuhan energi biologis manusia akan semakin kecil. Hal ini disebabkan karena penggunaan energi biologis erat kaitannya dengan lama pengeringan. Lama pengeringan sangat ditentukan oleh tinggi rendahnya suhu pengeringan.

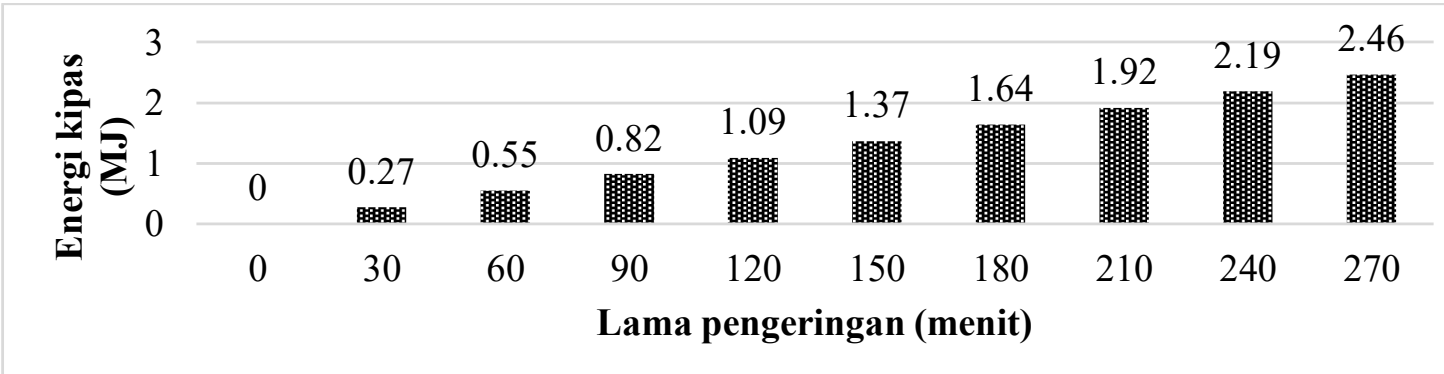

Gambar 9. Energi Kipas Pada Suhu $45^{\circ} \mathrm{C}$ 


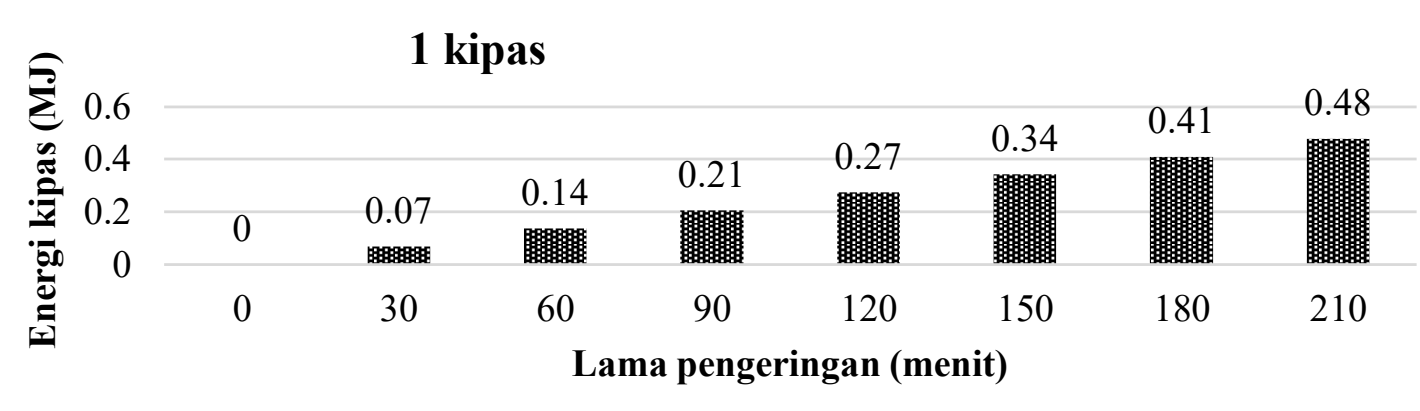

Gambar 10. Energi Kipas Pada Suhu $55^{\circ} \mathrm{C}$

Berdasarkan pada Gambar 9 menunjukkan adanya penggunaan energi kipas yang cukup tinggi dikarenakan suhu yang digunakan pada proses pengeringan lebih rendah dibandingkan suhu yang lain. Gambar 10 dan 11 menunjukkan adanya penurunan dalam penggunaan energi kipas dalam proses pengeringan bahan dikarenakan pada pengeringan ini suhu yang digunakan cukup tinggi dibandingkan sebelumnya.

\section{Energi Hilang Melalui Cerobong}

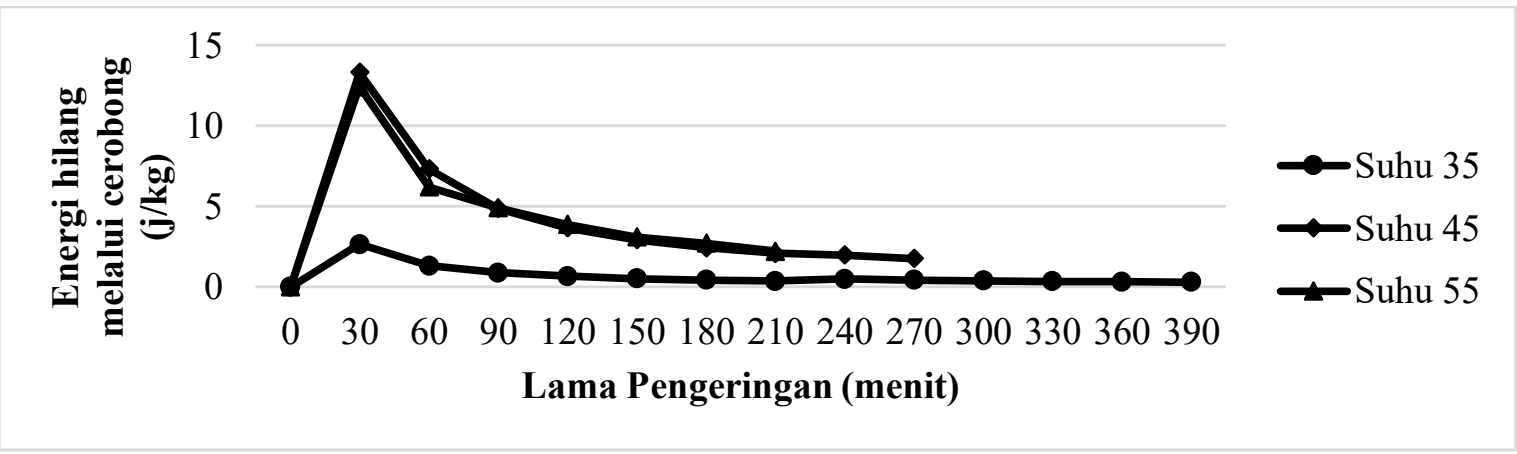

Gambar 11. Energi hilang melalui cerobong pada saat pengeringan bahan.

Berdasarkan pada Gambar 12 pada suhu $35^{\circ} \mathrm{C}$ didapatkan total energi sebesar $10,3 \mathrm{j} / \mathrm{kg}$, pada suhu $45^{\circ} \mathrm{C}$ sebesar $43,5 \mathrm{j} / \mathrm{kg}$ dan suhu $55^{\circ} \mathrm{C}$ total energi sebesar $39,3 \mathrm{j} / \mathrm{kg}$, semakin tinggi kecepatan angin maka semakin rendah energi yang hilang sebaliknya semakin rendah kecepatan angin semakin tinggi pula energi hilang melalui cerobong. 


\section{KESIMPULAN DAN SARAN}

\section{Kesimpulan}

Berdasarkan hasil penelitian yang telah dilakukan dapat diambil beberapa kesimpulan yaitu sebagai berikut :

1. Secara fungsional dan struktural alat pengering tray dryer setelah dimodifikasi dengan melapisi dinding luar ruang pengering dapat beroperasi dengan baik serta proses pengeringan lebih cepat dan energi yang dihasilkan lebih sedikit dengan sebelum dimodifikasi.

2. Konsumsi energi listrik pada alat pengering tray dryer setelah dimodifikasi pada saat proses pengeringan dengan suhu $35^{\circ} \mathrm{C}$ menggunakan energi listrik yang lebih besar $35,33 \mathrm{kWh}(127,2 \mathrm{MJ})$ dari pada pengeringan di suhu $45^{\circ} \mathrm{C}$ sebesar $24,26 \mathrm{kWh}(88,06$ $\mathrm{MJ})$ dan suhu $55^{\circ} \mathrm{C}$ sebesar $18,89 \mathrm{kWh}(68,01 \mathrm{MJ})$.

3. Konsumsi energi thermal selama proses pengeringan dengan suhu $35^{\circ} \mathrm{C}$ sebesar 17,53 MJ, suhu $45^{\circ} \mathrm{C}$ sebesar $19,54 \mathrm{MJ}$ dan suhu $55^{\circ} \mathrm{C}$ sebesar $21,34 \mathrm{MJ}$ Pada suhu $55^{\circ} \mathrm{C}$ didapatkan energi thermal lebih besar disebabkan oleh proses pengeringan lebih cepat.

4. Suhu yang paling baik pada saat proses pengeringan ialah suhu $55^{\circ} \mathrm{C}$ dikarenakan proses pengeringan lebih cepat dan konsumsi energi listrik yang dihasilkan lebih sedikit daripada suhu yang lain.

\section{Saran}

Perlu adanya modifikasi lanjutan pada alat pengering tray dryer ini dengan mengganti heater dengan daya yang lebih rendah agar dapat menghemat konsumsi energi listrik.

\section{DAFTAR PUSTAKA}

Eugene, C dan Hanapi, Gunawan. Drs.Ir.1993. Mesin dan Rangkaian Listrik. Edisi Keenam. ITB. Bandung.

Kamaruddin, A. 1994. Optimasi dalam perancangan alat pengering hasil pertanian dengan energi surya. Laporan Akhir Penelitian Hibah Bersaing Direktorat Pembinaan Penelitian dan Pengapdian Masyarakat.

Maulana, M. 2014. Uji performasi alat pengering hybrid (Surya-Listrik) tipe rak pada pengeringan kakao. Skripsi. Universitas Mataram, Mataram.

Puspa Swara. 20117. Jago Fisika SMP. Puspa Edukasi. Depok 